In relation to indirect discrimination, it was accepted that the respondent's requirement that all registrars should perform civil partnership ceremonies had the effect of placing persons of the claimant's religion or belief at a particular disadvantage and personally disadvantaged her. Since it was accepted that the promotion of equal opportunities and fighting discrimination was a legitimate aim, the key issue was whether it was proportionate. The EAT held that the tribunal had wrongly applied the proportionality test. The tribunal had held that it was not proportionate on the basis that the respondent had placed greater value on the rights of the gay community than on the rights of orthodox Christians. The EAT held that this was an erroneous approach: the question of proportionality was not a matter of giving equal respect to different communities, but of whether or not the means adopted to achieve a legitimate aim were proportionate. That test had been met. Requiring staff to act in a non-discriminatory manner was rationally connected with the legitimate aim and reasonably necessary to achieve that aim. Although Parliament had, in certain areas, permitted religious beliefs to take priority over the claims of those who sought not to be discriminated against on grounds of sexual orientation, such exceptions should be narrowly construed and no special exception had been carved out in respect of civil partnership duties. The EAT was also satisfied that its analysis was not inconsistent with Article 9 of the European Convention on Human Rights, which had adopted 'a very narrow protection indeed for employees'. There was thus 'no real doubt' that there would be any breach of Article 9 in this case. The argument advanced by Rix LJ in Copsey $v$ WBB Devon Clays Ltd [2005] EWCA Civ 932 that the line of authority did not apply when contractual variations were later imposed by the employer was unlikely to succeed here, where the extension of duties had been made by Parliament.

Summary supplied by Russell Sandberg. A fuller version appeared in Law and Justice, and it is reproduced here with permission.

\title{
Archdeacon of Rochester v Tripp and Northern
}

Disciplinary Tribunal, Diocese of Rochester, December 2008 Adultery - desertion - public scandal - penalty

The respondents, who were, respectively, Rector and Associate Rector of the same benefice, admitted deserting their respective spouses and setting up home together. The tribunal therefore considered only the penalty to be imposed. The Bishop of Rochester recommended that both be prohibited from ministry for life, on the grounds that abandoning their parish without 
notice, deserting their spouses, causing a public scandal and forming an inappropriate relationship meant that he could never again be able to recommend them for ministry. The tribunal found that there was a realistic possibility that the second respondent could, at some point in the future, take up ministerial functions again. She was prohibited for twelve years and the first respondent for life. Both were removed from office and placed on the Archbishops' List. [WA]

doi:10.1017/So956618Xo9002221

\section{Re St Nicholas, Nuneaton \\ Coventry Consistory Court: Gage Ch, January 2009 \\ Reordering - new room - removal of organ}

The petition before the court was in two parts. The first concerned the construction in the churchyard of a community hall to be connected to the Grade I listed church and the neighbouring Grade II listed former grammar school. There were no objections and the scheme had received the necessary planning permission and listed building consent. The faculty for this was granted subject to conditions about the recording and reburial of any remains disturbed. The second part attracted three objections and concerned the removal of pews, the installation of a new heating system, the installation of a dais at the chancel end of the nave, the construction of meeting rooms within the south-west corner of the church, the removal of the pipe organ to make way for a new vestry and other sundry matters. The hearing was principally about the removal of the organ and its replacement with a digital instrument. The chancellor reviewed the law set down principally in the Bishopsgate questions. He was satisfied that the petitioners had shown the necessity for the proposed works. He also considered that the works would adversely affect the character of the church as a building of significant historical and architectural interest. $\mathrm{He}$ was satisfied that the necessity outweighed the adverse effect in respect of the majority of the proposed works. However, the organ (which he considered to be a fixture, rather than a chattel) was of local and historic interest. He found that the removal and possible re-use of the organ elsewhere had not been considered and that proper consideration had not been given to the siting of the vestry in one of the proposed new rooms in the south-west of the church. A faculty was granted for the second part of the petition, save for the removal of the organ. [WA] 